\author{
تاثير لجن فاضلاب شهرى بر ويزّى هاى شيميايى، تنفس و زيست توده ميكروبى \\ يك خاك آهكى لوم سيلتى رسى \\ نسرين كريميان شمس آبادى، شجاع قربانى دشتكى * و فايز رئيسى'

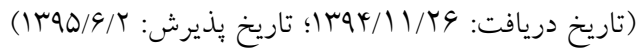

جكيده

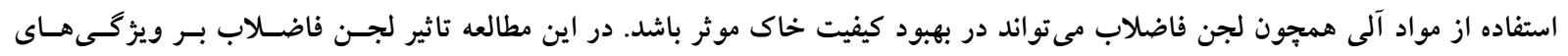

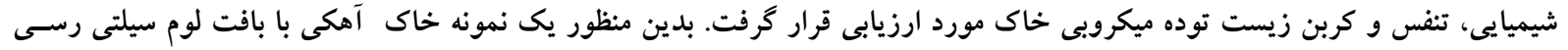

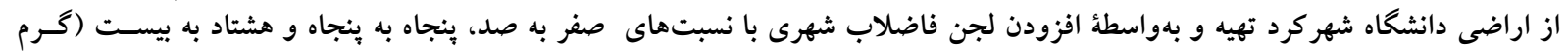

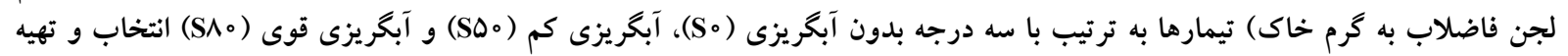

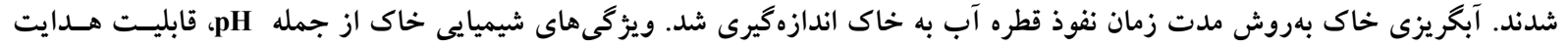

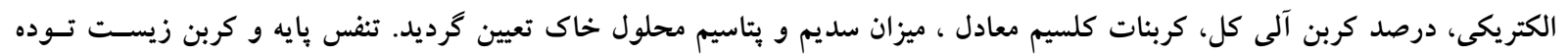

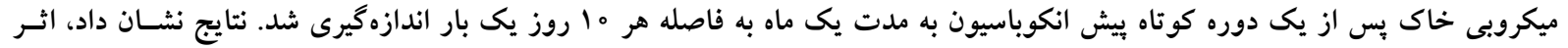

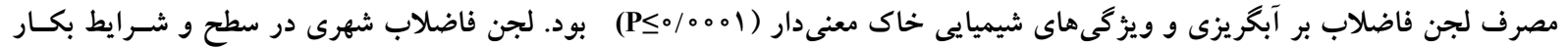

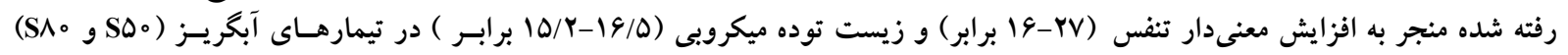

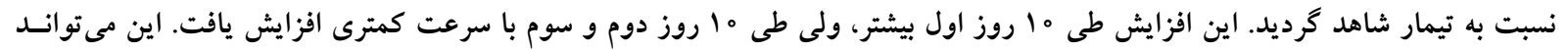

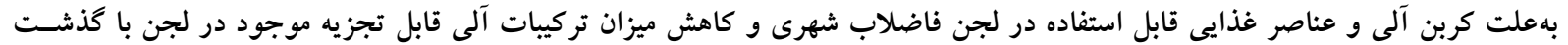

وازمهاى كليدى: تنفس ميكروبى، زمان نفوذ قطره آب، كربن زيست توده ميكروبى، لجن فاضلاب شهرى 
مرطوب شدن مقاومت نشان مىدهد (1/). دليل اصلى آبخريزى

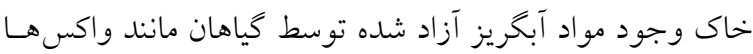

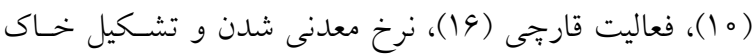

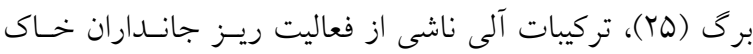

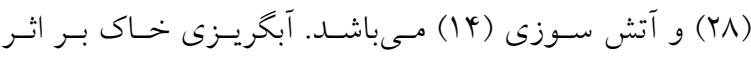

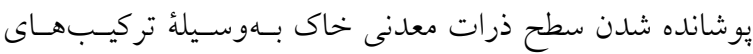

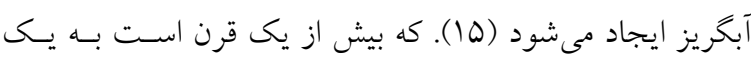

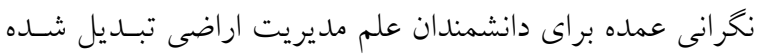

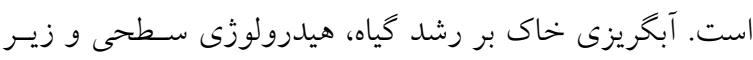

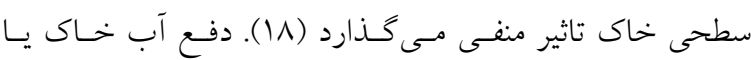

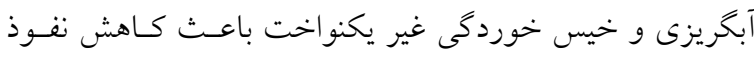

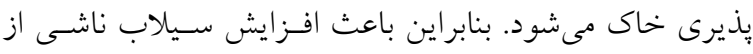

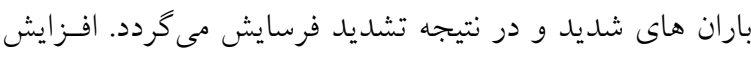

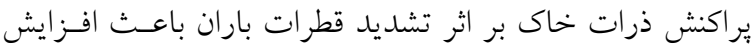

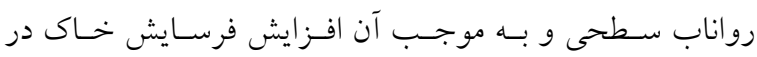
مناطق شيب دار مسىشـود. بنـابراين مــيريت ايـن خـاكهـا و

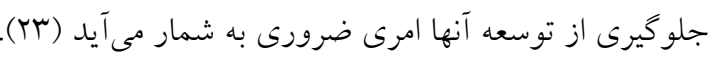

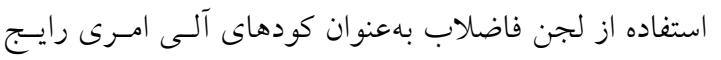

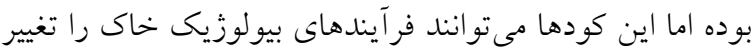

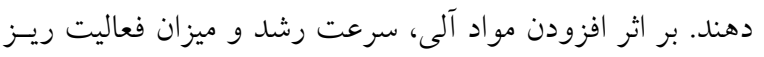

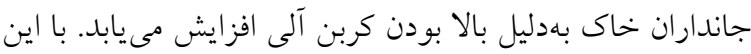

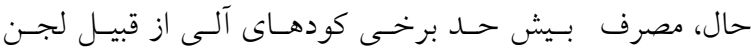

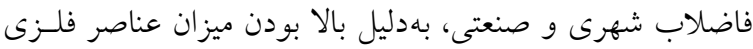

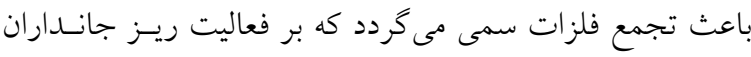

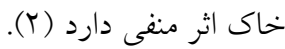
نتايج برخى مطالعات بر افزايش تنفس خاك داك ناشى از مصـرف لجن فاضلاب دلالت دارد، كه مىتوانـــ بـهدليـل افـزايش ميـزان

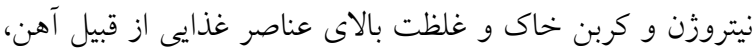
روى، مس و منكنز در لجن فاضلاب باشـــ (V). لجـن فاضـلاب اثر قابل توجهى بر فعاليت و جمعيت ميكروبى خـاك دارد (YI).

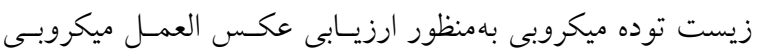
خاك به مديريت، تغييرات زيست محيطى، بهم خوردگ زئى زيستخاه

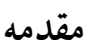

استفاده از يّاب و لجن فاضلاب مىتوانــ يكى از منـابع آلـوده كننده محيطى در اراضى كشاورزى باشد. لجن فاضلاب و يّـاب

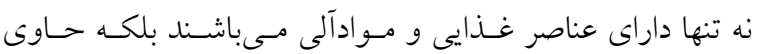

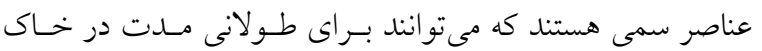
انباشت و با كذشت زمان غلظت آنها در خاك زيـاد كـردد (آس). لجن فاضلاب نوعى از يُماندهاى آلى است كسه باعت افـزايش

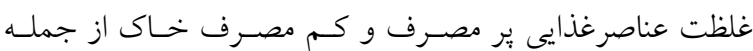

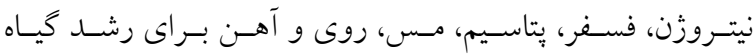

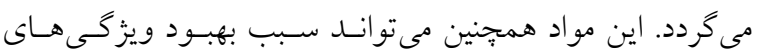

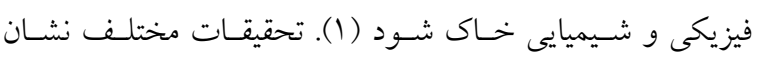
مىدهد كه بِماندهاى آلى بهدليل دارا بودن مقادير زياد تركيبـات

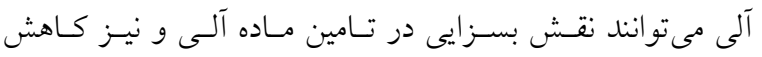

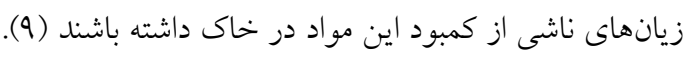

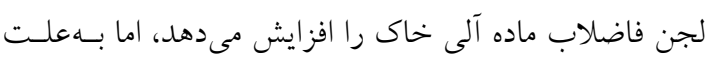
وجود تركيبات آبخريز باعث كاهش قابليت مرطوب شدن شادن خـاك

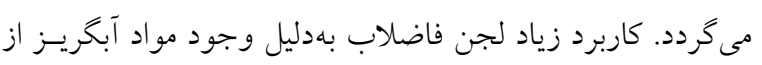

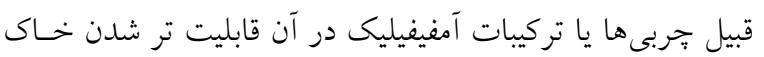

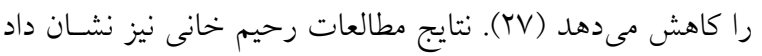
كاربرد مقادير مختلف لجن فاضلاب شهـرى اثـر معنسىدارى بـر

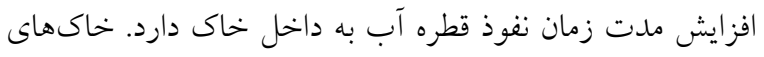

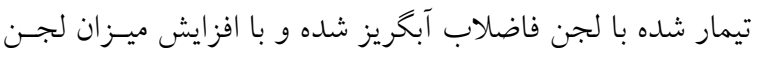

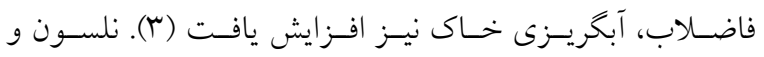

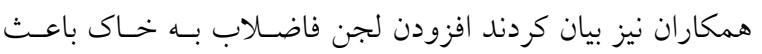

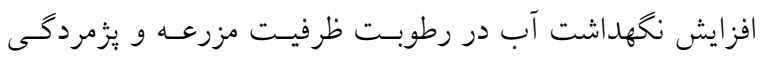

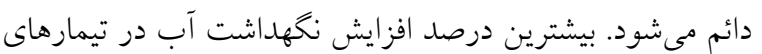
با درصد لجن زياد و بافت درشت مشاهده شد (؟) ).

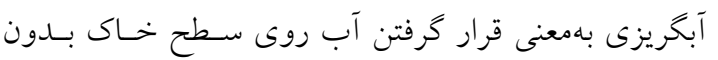

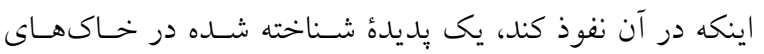

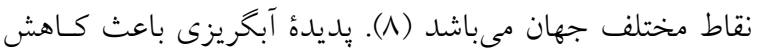

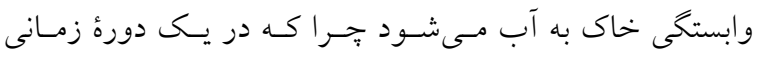

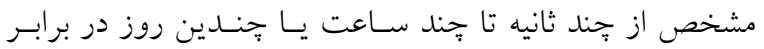


شهركرد واقع در استان جهارمحال و بختيارى از عمق صـفر تـا

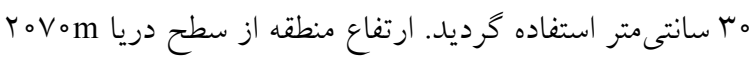

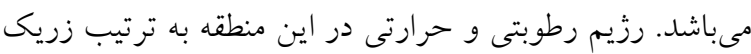

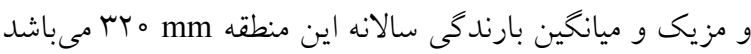

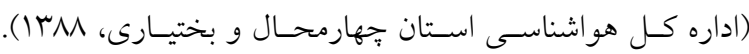

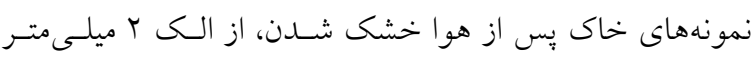

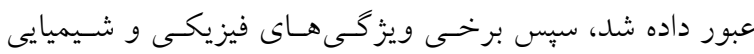

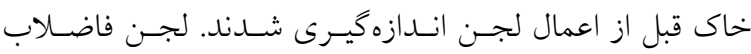

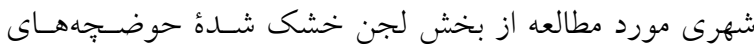

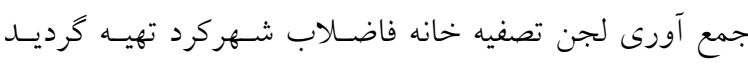
(سيستم تصفيه فاضلاب در اين تصفيه خانه سيستم لجـن فعـال

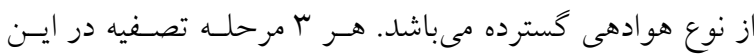

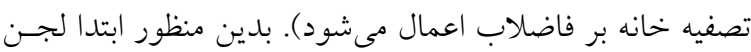

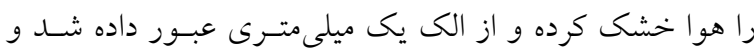

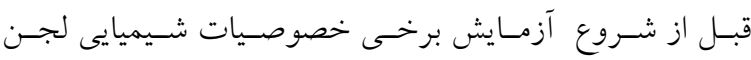

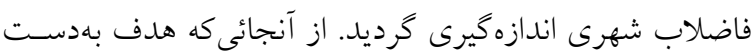

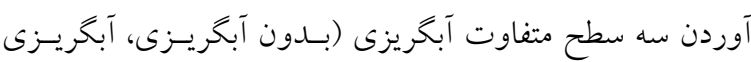

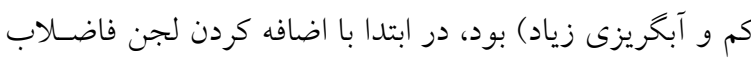

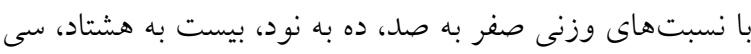

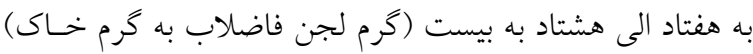

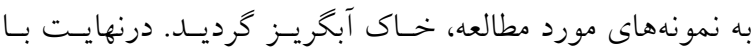

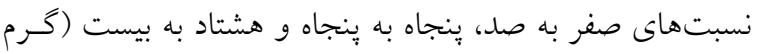

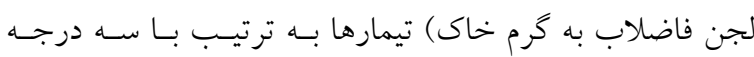

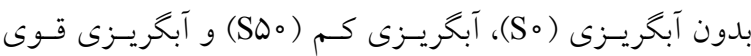
(SA。)

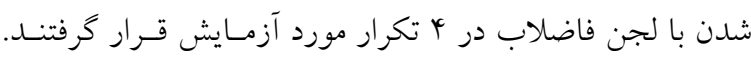

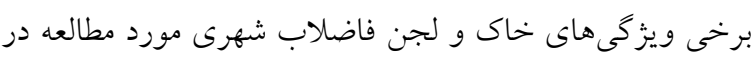
جدول (1) ارايه شده است. با استفاده از روش تست قطره اندازميرى و الخـــى دكـر و

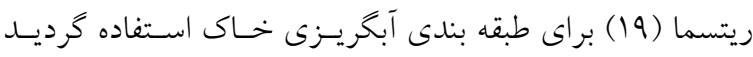

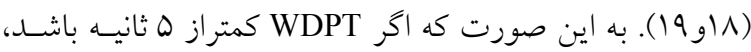

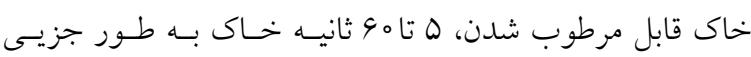

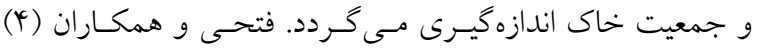

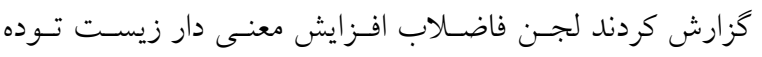

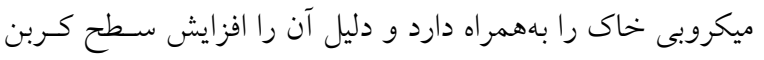

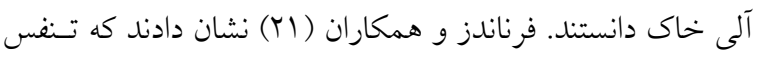

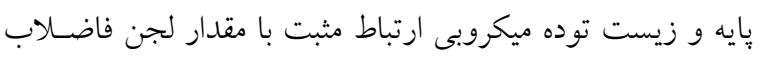
دارد و با افزايش مقدار لجن افزايش يافتند.

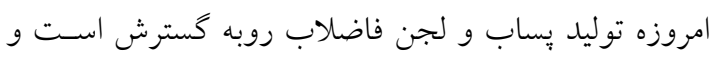

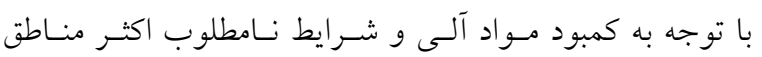

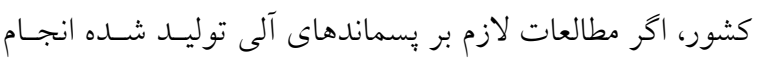

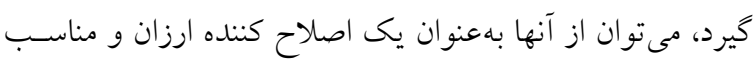

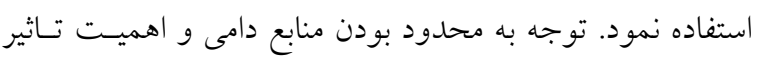

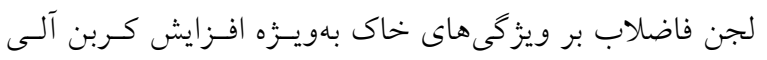

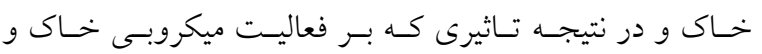

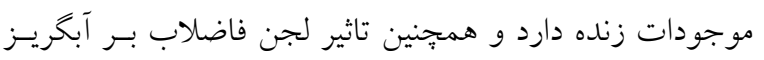

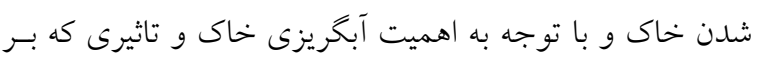

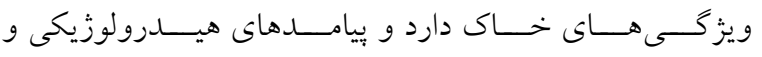
زُئومورفولوزيكى دفع آب خاى كه مشهودترين آن، كاهش نفوذ دارد

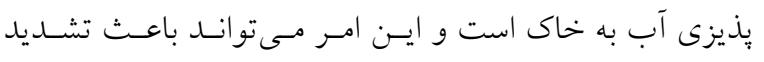

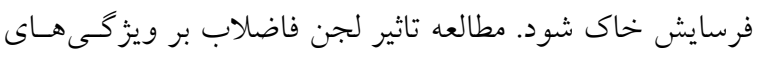

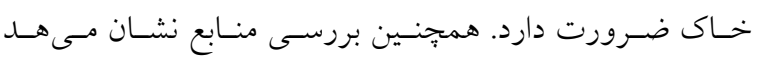

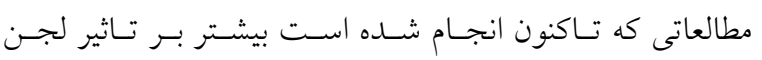

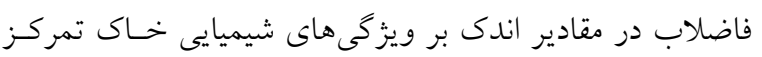

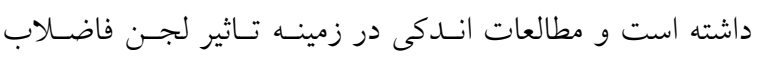
شهرى در مقادير زياد بر ويزگى هـاى بيولـوزيكى، شـيميايى و

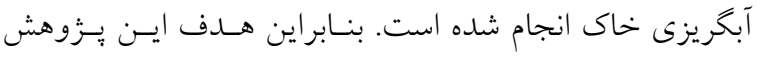

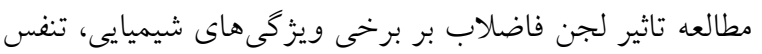
و زيست توده ميكروبى يك خاك آهكى لوم سيلتى رسى بود.

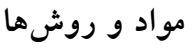

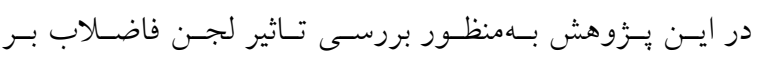

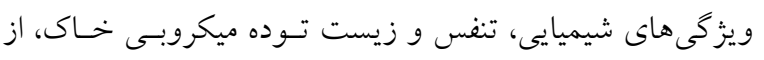

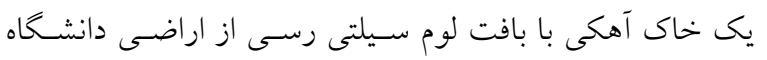


نشريه علوم آب و خاك (علوم و فنون كشاورزى و منابع طبيعى) / سال بيست و يك / شماره يك/ بهار وهجا

\begin{tabular}{|c|c|c|c|}
\hline لجن & خاك & واحد & ويزگگى \\
\hline- & $1 \% / Y_{0}$ & $(\%)$ & شن (Sand) \\
\hline- & $\Delta r / q \circ$ & $(\%)$ & سيلت (Silt) \\
\hline- & $r r / 90$ & $(\%)$ & رس (Clay) \\
\hline $9 / V_{0}$ & $V / T_{0}$ & - & $\mathrm{pH}\left(\mathrm{H}_{r} \mathrm{O}\right)$ \\
\hline$r / q_{0}$ & $\circ / \mu_{0}$ & $(\mathrm{dS} / \mathrm{m})$ & $\mathrm{EC}\left(\mathrm{H}_{\digamma} \mathrm{O}\right)$ \\
\hline rq/V。 & $\circ / \wedge \circ$ & $(\%)$ & كربن آلى (OC) \\
\hline$r / \mu$ & r。 & $(\%)$ & كربنات كلسيم معادل (CaCO$)$ \\
\hline
\end{tabular}

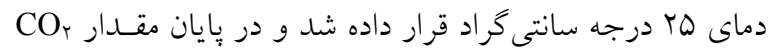

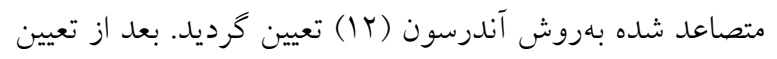

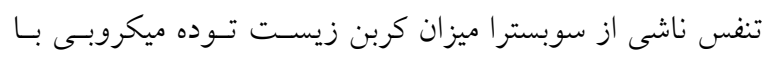

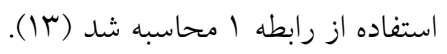
$\operatorname{MBC}\left(\mathrm{mg} \mathrm{C} \mathrm{kg}^{-1}\right)=\left(\kappa_{\circ} / \circ \mathrm{ml} \mathrm{CO}_{\Upsilon} \mathrm{kg}^{-1}\right)+\circ /{ }_{\mathrm{rV}}$

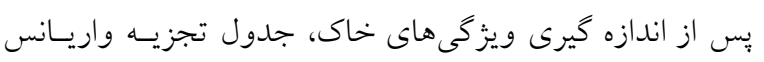
(ANOVA)

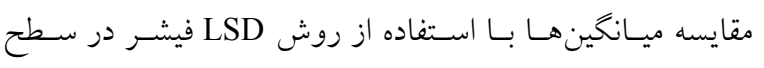
احتمال هـ در قالب طرح بايه كاملاً تصادفى مورد ارزيابى قـرار

\section{نتايج و بحث}

\section{اثر لجن فاضلاب بر آبخريزى}

در اين يزوهش براساس الخوى طبقه بندى دكر و ريتسـما (19)

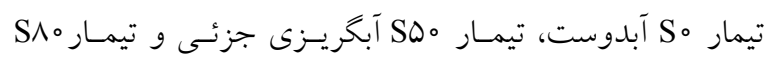

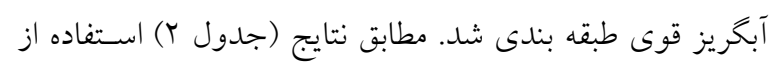

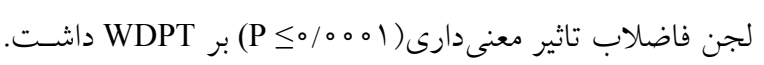

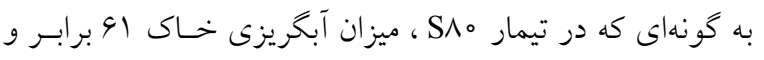
در تيمار T50 S50 برابر شد (جدول r). لجن فاضـلاب بـهدليـل

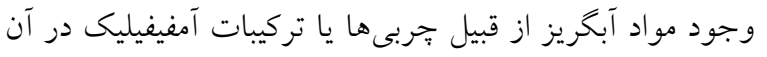

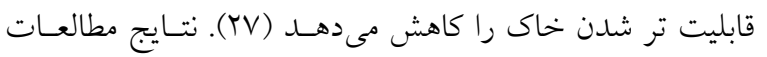

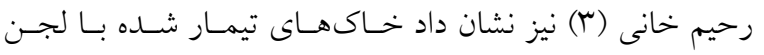

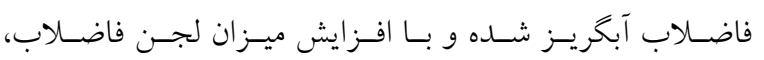

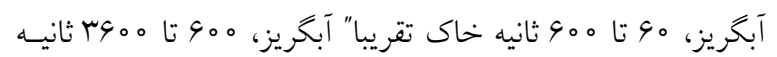

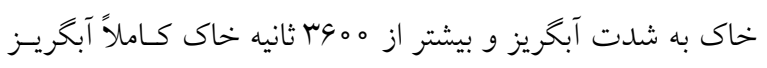

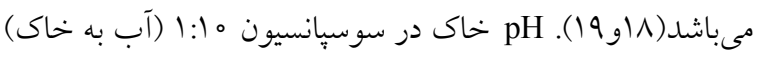

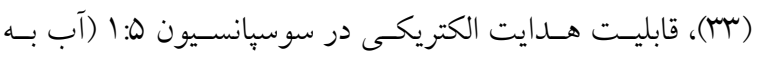

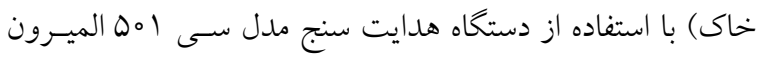
(C 501 Elmeiron)

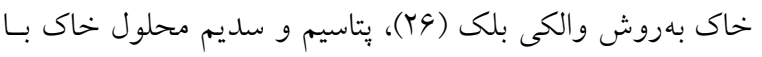

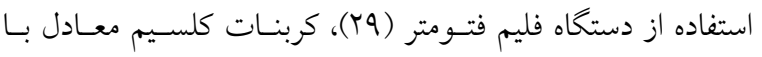

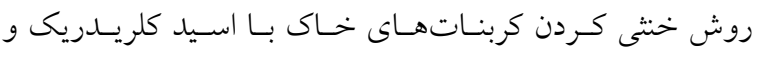

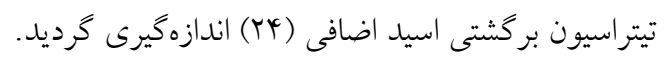

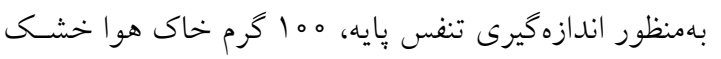

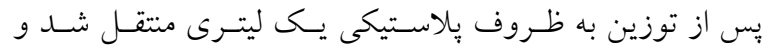

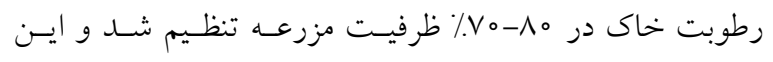
رطوبت تا بايان آزمايش با توزين متوالى كنترل كرديد. نمونههـا

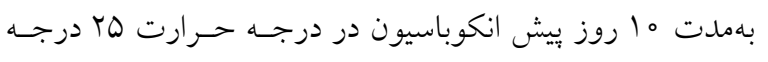

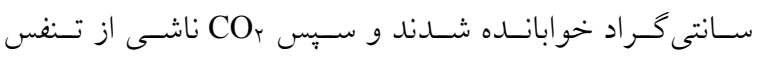

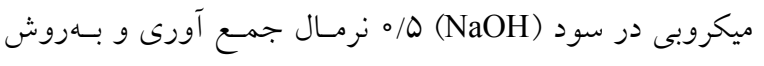

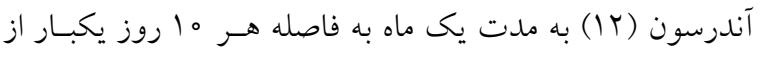

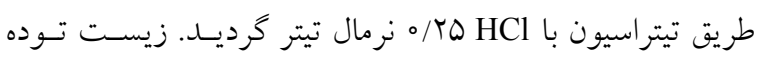

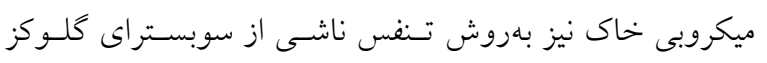

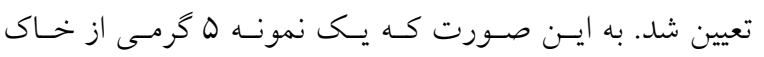

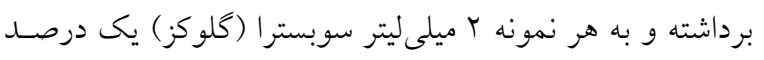

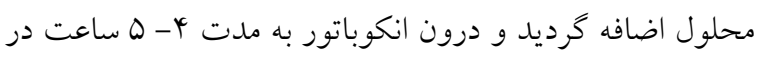


تاثير لجن فاضلاب شهرى بر ويزّكىهاى شيميايى، تنفس و زيست توده ...

جدول r. نتايج تجزيه واريانس (ميانگين مربعات) اثر مصرف لجن فاضلاب بر برخى خصوصيات خاك مورد مطالعه

\begin{tabular}{|c|c|c|c|c|c|c|c|}
\hline WDPT & $\mathrm{pH}$ & $\mathrm{OC}$ & K & $\mathrm{Na}$ & $\mathrm{CaCO}_{r}$ & $\mathrm{df}$ & منبع تغيير \\
\hline is & $\circ / \mu_{\circ} \circ$ & $1 \pi / 90$ & $\Delta / \wedge \mathcal{F}$ & $1 \% / 9 V$ & $9 / 4 \pi$ & r & لجن فاضلاب \\
\hline $0 / 94$ & $0 / 001$ & 01019 & \% \% & $0 / 009$ & $\circ / 0 \circ \wedge$ & 9 & خطا \\
\hline $1 / 1 \circ$ & $0 / 40$ & $Y / Y G$ & $0 / 90$ & س & $Y / Y I$ & - & ضريب تغييرات(\%) \\
\hline$\leq 0 / 0001$ & $\leq 0 / 0001$ & $\leq 0 / 0001$ & $\leq 0 / 0001$ & $\leq 0 / 0001$ & $\leq 0 / 0001$ & & $\operatorname{Pr}>F$ \\
\hline
\end{tabular}

جدول r. مقايسه ميانگين (n=p) اثر مصرف لجن فاضلاب شهرى بر برخى خصوصيات خاى

\begin{tabular}{|c|c|c|c|c|}
\hline & تيمار & & & \\
\hline S80 & S50 & S0 & واحد & ويزگى \\
\hline $41 \mathrm{~A}$ & $r \Delta^{\mathrm{B}}$ & $1^{C}$ & $\mathrm{sec}$ & WDPT \\
\hline $4 / N^{\circ} \mathrm{C}$ & $V / / 0^{B}$ & $V / F_{0} \circ A$ & - & $\mathrm{pH}$ \\
\hline $199^{\mathrm{A}}$ & $11 V^{B}$ & $\Lambda^{\mathrm{C}}$ & $(\mathrm{g} / \mathrm{kg})$ & OC \\
\hline$\Lambda / V^{\circ} \mathrm{C}$ & $19 \mathrm{~B}$ & $r_{0} A$ & $(\%)$ & $\mathrm{CaCO}_{r}$ \\
\hline r19A & $194^{c B}$ & IrYC & $(\mathrm{ppm})$ & $\mathrm{Na}$ \\
\hline MA & r。oB & $\left.r \&\right|^{C}$ & $(\mathrm{ppm})$ & $\mathrm{K}$ \\
\hline
\end{tabular}

با بررسى اثر لجن فاضلاب بر ويزز گهـاى خـاك گـزارش كـرد كاربرد لجن فاضلاب باعث كاهش اسيديته خاى مى گردد. وجود آمونيوم در لجن فاضلاب نيز باعث تشديد فرآيند نيترات سـازى

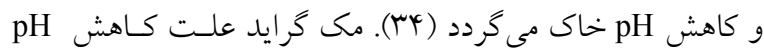
خاى بر اثر افزايش لجن فاضلاب را تجزيه مواد آلى و اكسـايش كو گرد بيان نمودند (YQ) افزايش مصرف لجن تاثير معنى دار ( P

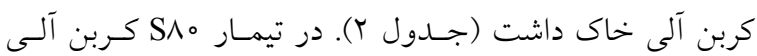

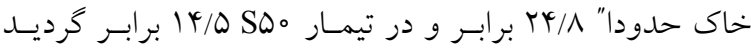
(جدول r). افزايش كربن آلى خاى مىتواند بهعلت غنى بـودن لجن فاضلاب از كربن آلى باشد. نتايج اين يزوهش با مطالعـات رحيم خـانى (r) و نورمهنـاد (9) همخــوانى داشـت. اوجــدا و همكاران (YV) نيز بيان نمودند لجن فاضلاب، مواد آلى خاى را افزايش مىدهد اما قابليت مرطوب شدن خاك را بهدليل وجـود تركيبات آبخريز كاهش مىدهد و ماده آلى در همـأ خـاكهـاى
آبكريزى خاى افزايش يافت. نتايج ايسن بـزّوهش بـا مطالعـات نورمهناد (9) نيز مطابقت داشت.

\section{اثر لجن فاضلاب بر ويزگىهاى شيميايى خاك} نتايج جدول (Y) نشان مىدهد لجن فاضلاب شهرى اثر معنى دار

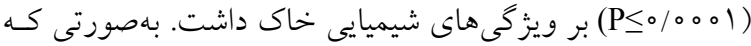
با افزايش سطح لجن، كربن آلى، سديم محلول و يتاسيم محلـول خاى افزايش يافتند جدول (r). ولى افزايش لجن فاضلاب باعث كاهش واكنش خاى و كربنات كلسيم معادل گرديد (جــدول ش). همانطور كه جدول ب نشان مىدهد در تيمار مA واكـش خـاك

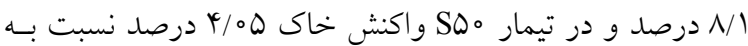
تيمار شاهد كاهش يافت، كه اين كاهش مىتواند ناشى از وجـود اسيدهاى آلى و تركيبات اسيدزا در لجـن فاضـلاب باشــ (11). نتايج حاصل از مطالعات شارما و همكاران (rr) نيز تاييد كنــده كاهش pH خاى يس از كاربرد لجن فاضلاب بود. إِــتين (Yo) 
نشريه علوم آب و خاك (علوم و فنون كثاورزى و منابع طبيعى) / سال بيست و يك / شماره يك/ بهار وه؟1

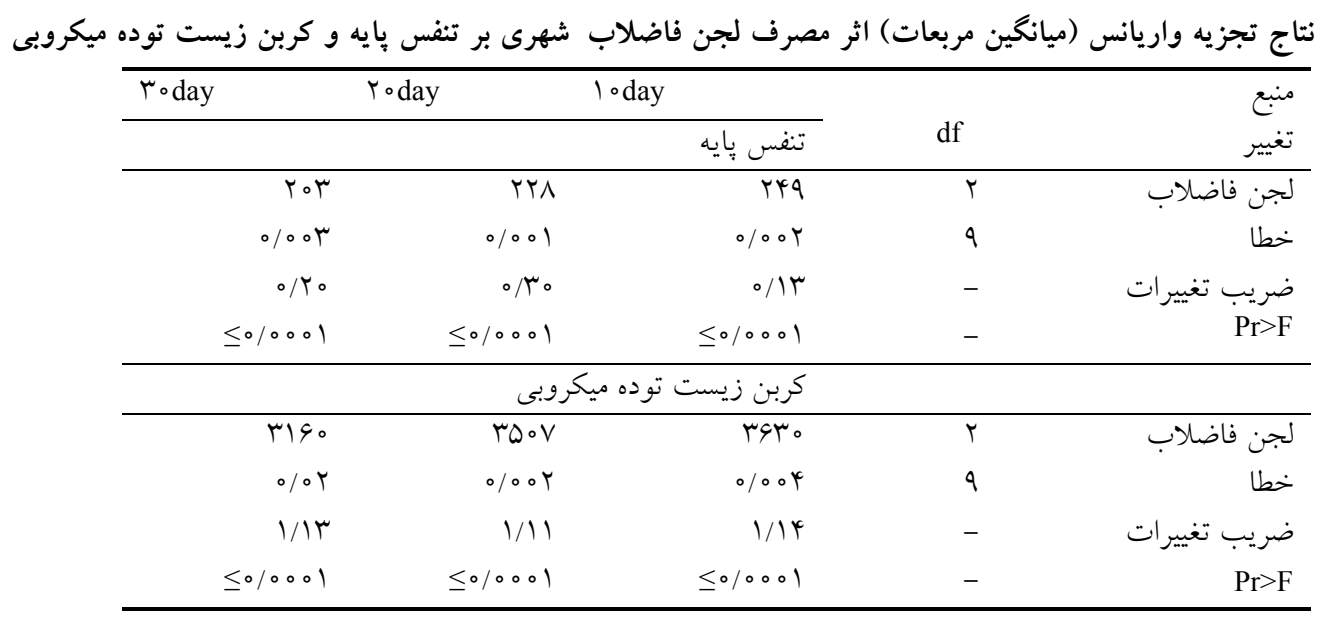

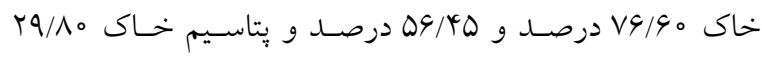
درصد و 1 1 ا درصد نسبت به تيمار شاهد افزايش يافت. اين موضوع با مطالعات رحيم خـانى همخــوانى دارد (r). نورمهنـاد نيز گزارش كرد با افزودن لجن فاضلاب ميزان سديم و يتاسـيم محلول افزايش يافـت (9). قمـرى و دانسش بـا بررسـى اثـرات كاربرد لجن فاضلاب بر خصوصيات خاك دريافتند كـه كـاربرد لجن فاضلاب موجب افزايش مقدار يتاسيم قابل دسترس خـاك كرديد (ه). آنها بيان نمودند، با ايسن وجـود يتاسـيم موجـود در لجن فاضلاب معمولا كم بوده و كاربرد لجـن در مقـادير كـم و متوسط تاثير زيادى بر يتاسيم خاك نداشته و بههمـين علـت بـا كاربرد لجن فاضلاب بهتر است كود يتاسـيم دار نيـز بـه خـاك افزوده شود. بهطور كلى تاثير لجن فاضـلاب بـر مقـدار يتاسـيم خاك نسبت به عناصر ديخر كمتر بـوده كـه مسى تـوان آن را بـهـ مقدار كم يتاسيم موجود در لجن ارتبـاط داد. دليـل اصسلى ايسن

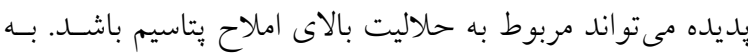
اين علت كه يس از جدا شدن لجن از فاضلاب، يتاسيم بهطـور

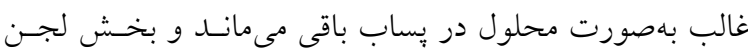
حاوى يتاسيم كمترى خو اهد بود (بم).

اثر لجن فاضلاب بر تنفس پايه خاك

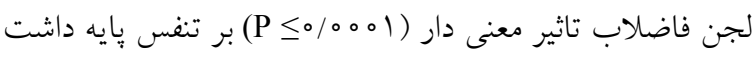

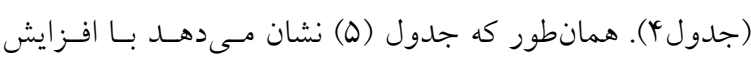

آبخريز به وفور يافت مىشود. واثقى و همكاران با بررسسى اثر لجن فاضلاب بر ميزان ماده آلى خاكهاى با PH متفـاوت بيـان نمودند لجن فاضلاب باعث افزايش ماده آلى خاى مىشود كـه اين افزايش با مقدار لجن اضافه شده به خاك رابطه مستقيم دارد

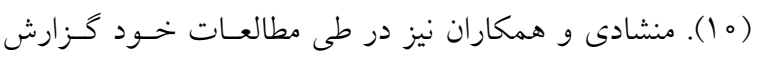

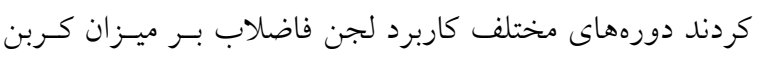
آلى خاى تاثير معنىدارى داشت و بيان كردند بخش كربن فعال موجود در لجن فاضلاب، يس از افزوده شده بـه خـاك تجزيسه كرديده و بخشى از كربن موجود در اين كود به ذخاير كربن در خاى بيوسته و باعث افزايش سطح ماده آلى خاك مىشود (9).

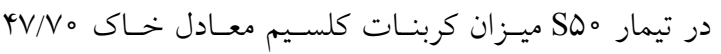
درصد و در تيمار D SA درصد نسبت به تيمـار بــدون لجـن كاهش يافت (جدول ץ). لجن فاضـلاب سرشـار از كـربن آلى لـ است. در اثر تجزيه بيولوزيكى لجن فاضلاب يكسرى تركيبـات

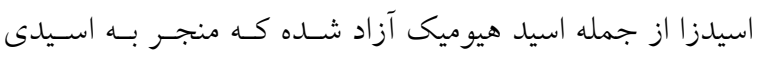
شدن و درنهايت منجر به غير فعال شدن كربنات كلسيم (خنثى شدن يونهاى قليايى) در خاى مىشود. بنابر اين درصد كربنـات كلسيم معادل در اين خاكها در مقايسه با خاكهايى كـه بــدون

$$
\text { لجن فاضلاب كمتر بود (r). }
$$

براساس نتـايج بـهدسـت آمــده از ايسن بـرّوهش اثـر لجـن فاضلاب بر افزايش سديم و يتاسيم محلول خاك معنسى شار شـد

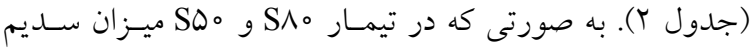




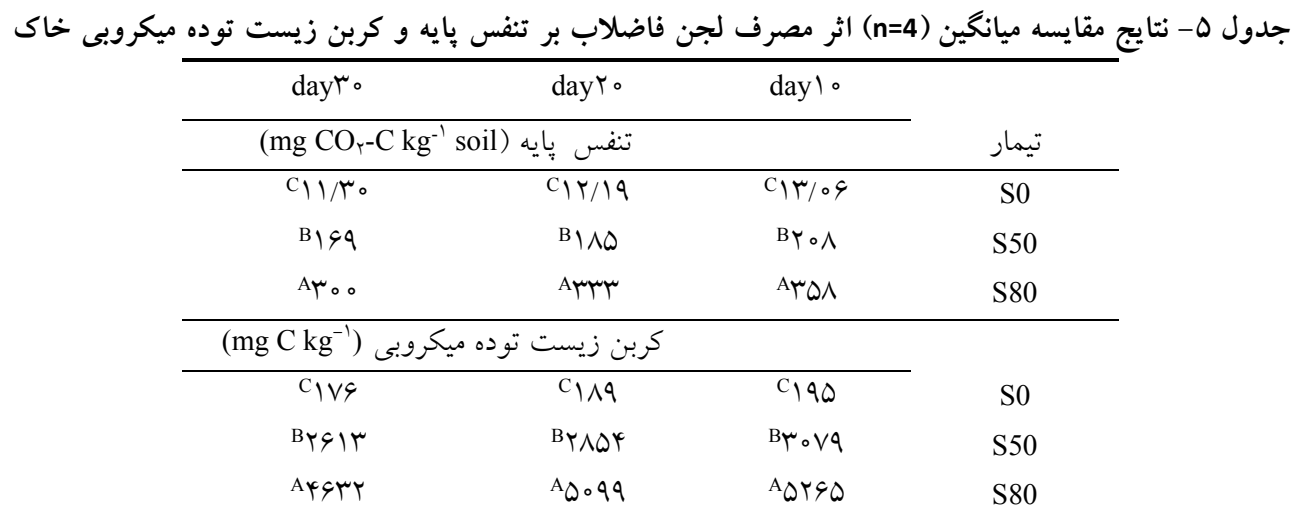

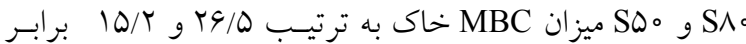
كرديد. اين نشان مىدهد كه ريزجانداران در خاك مورد مطالعـه با محدوديت شديد كربن و ساير عناصر غذايى روبرو هسـتند. زيست توده ميكروبى جزء زندهُ ماده آلى خاك است كـه شـامل باكترى و قارج و همجنين ميكروفون و جلبكهاى ريز مىباشد و نقش كليدى در بوياى مواد آلى و جرخحه عناصر غذايى خـاك ايفا مى كند (YY). حجتى و همكاران كاربرد سطوح مختلف لجن را بر زيست توده ميكروبى خاك را بررسسى و نشـان دادنــد بـا افزايش سطح لجن، زيست توده ميكروبى خاك افزايش يافت و دليل آن را افزايش سطح كربن آلى دانستند و بــا افـزايش كـربن آلى ميزان سوبستراى مورد نياز جمعيـت ميكروبسى هتروتـروف

افزوده شده و جمعيت ميكروبى افزايش مى يابد (Y). فتحى و همكاران طى مطالعـات خــود بيـان نمودنـــ لجـن فاضلاب اثرات مثبت بر خصوصيات بيولوزيكى خاك دارد و در سطح و شرايط بكار رفته شده باعث افزايش تـنفس و جمعيـت ميكروبى خاك تيمار شده با لجن فاضلاب نسبت به خاى شاهد مىشود (Y). مارى نارى و همكاران نيز دريافتنـد كميوسـتهـا حاوى تعداد زيادى از جو امع ريزجانداران هستند و بنـابراين بـا مصرف كميوست علاوه بر افزودن مواد آلى و عناصر غذايى در خاك، موجودات زنده نيز وارد خاى مىشوند (9). زيست توده ميكروبى بهسرعت و در كوتاه مـــت بـه ورود كربن آلى از منابع مختلف ياسخ مى دهد و جِون اغلب خاكهـا

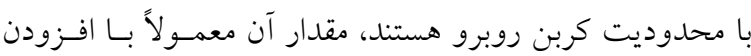

سطوح لجن فاضلاب تنفس ميكروبى افزايش يافت (جدول ه). طى يك ماه انكوباسيون در هر ب فاصله زمانى بيشـترين مقـدار COr تيمار S0 بود و در تيمار \&SA و SO ميزان تنفس بايه به ترتيب TV علت افزايش تنفس ميكروبى مىتواند افزايش سطح كربن آلى و عناصر غذايى بر اثر افزايش ميزان مصرف لجن فاضلاب و رفـع كمبود آنها در خاى مورد مطالعه باشد. دار بيان كرد كاربرد لجـن فاضـلاب باعـث افز ايش ميـزان نيتروزن و كربن موجود در خاى مى گردد و از اينـرو مسىتوانـد منجر به افزايش تنفس ميكروبى در خاك شود (IV). فرنانـدز و همكاران نيز بيان نمودند افزودن لجن فاضلاب، تـنفس بايسه را افزايش مىدهد كه مىتواند بهدليل افزايش مقدار مواد آلى قابـل دسترس در خاك مىباشـــ (T). افـزايش مــواد آلـى و عناصـر غذايى در خاك سبب تحريك فعاليـت زيسـت تـوده ميكروبسى شده و در نتيجه سطح تـنفس بايسه بـالا مسىرود. آنهـا كـزارش نمودند تنفس يايه در تيمار لجن فاضلاب نسبت به تيمار شـاهد افزايش زيادى نشان داد (YI).

\section{اثر لجن فاضلاب بر كربن زيست توده ميكروبى خاك}

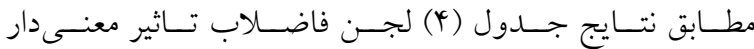

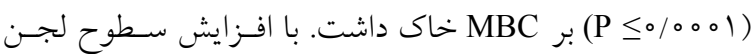
كاربردى MBC افزايش يافت (جدول ه). بهكونهاى كه در تيمار 
باعث كاهش pH و ميزان كربنات كلسيم معادل شد. احتمالاً اين كاهش مىتواند ناشى از وجود اسيدهاى آلى و تركيبات اسـيدزا در لجن فاضلاب باشد. افزايش لجن فاضلاب منجر به افـزايش

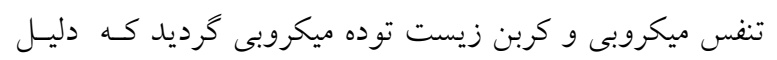

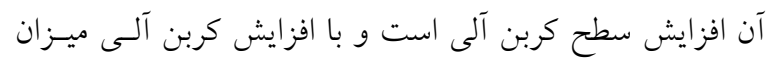

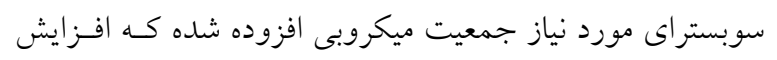
جمعيت ميكروبى را به همر اه دارد.

\section{سباسكزارى}

بدين وسيله از دانشخاه شهركرد بهدليل حمايتهاى مالى از اين

$$
\text { تحقيق تشكر و قدردانى مى كردد. }
$$

منابع حاوى كربن سهل الوصول به خاك افزايش مىيابــ (YT).

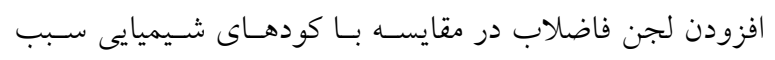

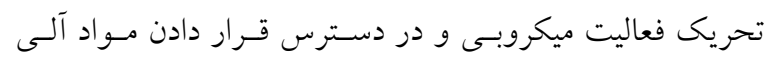

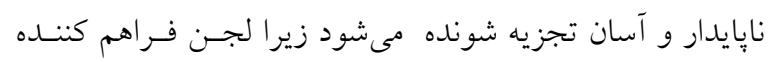
منابع جديدى از كربن و انرزى در خاك است (Y) (Y).

\section{نتيجه گيرى}

بر اساس نتايج اين مطالعه لجن فاضلاب منجر به آبخريز شـدن

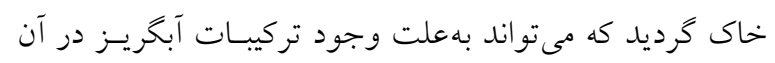
باشد. افزايش مصرف لجن فاضلاب باعث افزايش مقدار كـربن

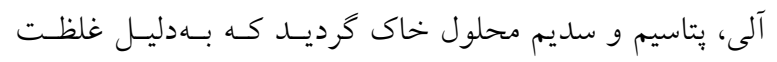
بالاى اين عناصر غذايى در لجن است. افزودن لجـن فاضـلاب

\section{منابع مورد استفاده}

ا. بوستانى، ح.ع، رونقى. هq ا. مقايسه اثر كاربرد لجن فاضلاب و كود شيميايى بر عملكرد و غلظت برخى عناصر غذايى در كيـاه

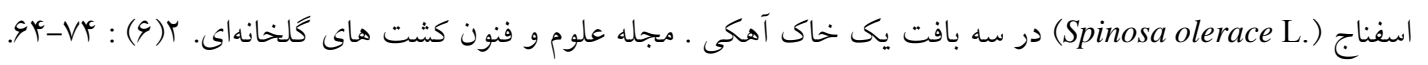

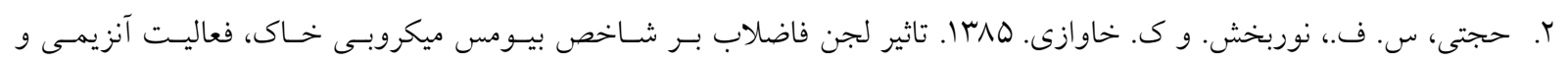

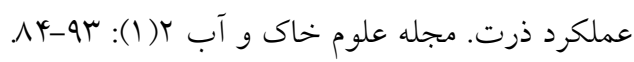

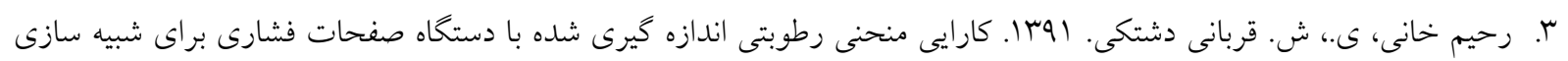

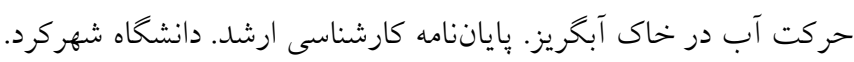

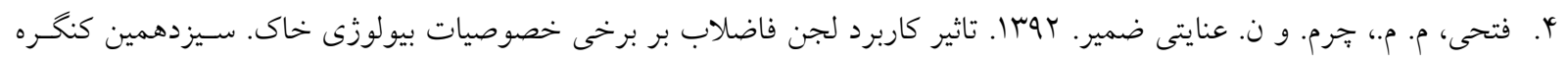

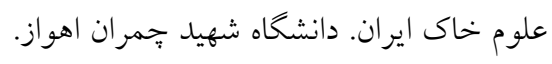

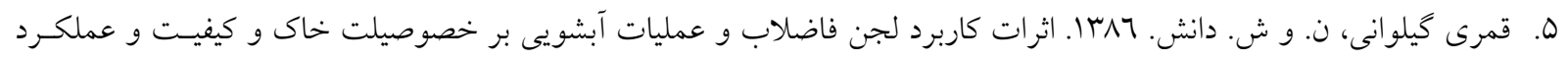

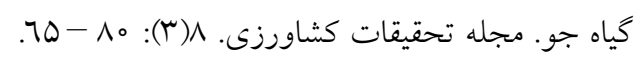

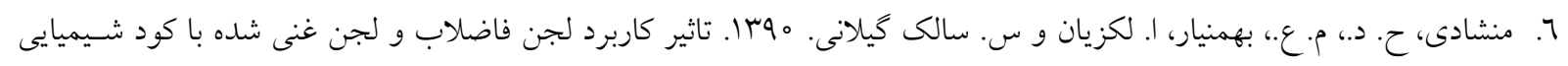

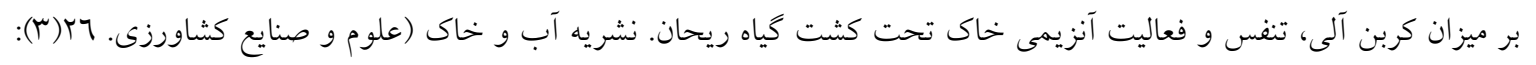

$$
\Delta \Delta Y-\Delta T T
$$

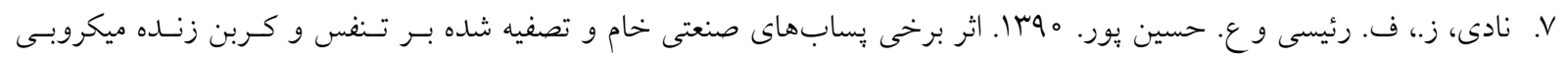

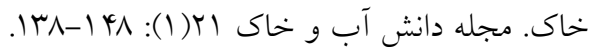

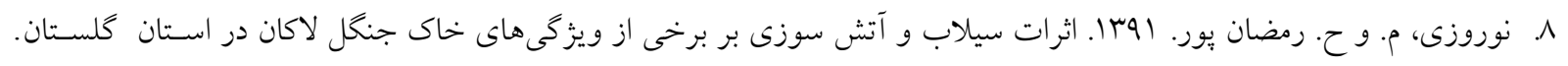

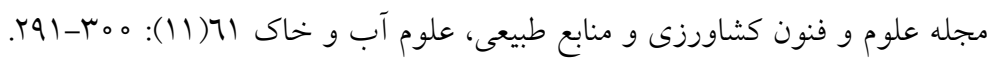
9. 


$$
\begin{aligned}
& \text { كنوختن در خاك هاى آبدوست و آبخريز شده در اثر حرارت. مجله يثوهش هاى (علوم خاى و آب) rV(Y): }
\end{aligned}
$$

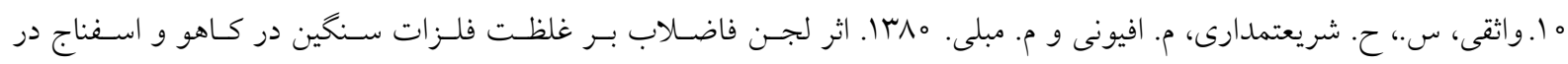

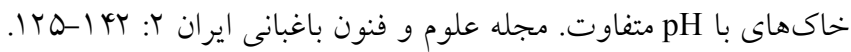

11. Afyuni, M. 1987. Extractability of Fe, Zn, and Cd in sludge amended calcareous soils. M.sc Thesis. New Mexico State University, Las Cruces, NM.

12. Anderson, J. P E. 1982. Soil respiration. PP. 831-871. In: Page AL, Miller RH and Keeney DR (Ed.), Methods of Soil Analysis, Part 2: Chemical and Microbiological Properties, 2nd ed. Soil Sci. Soc. Am., Madison, WI, USA.

13. Anderson, J. P. E. and K. H. Domsch. 1978. A physiological method for the quantitative measurement of microbial biomass in soils. J. Soil Biol. Biochem. 10: 215-221.

14. Arye, G., J. Tarchitzky and Y. Chen. 2011. Treated wastewater effects on water repellency and soil hydraulic properties of soil aquifer treatment infiltration basins. J. Hydrol. 397: 136-145

15. Burch, G. J., J. D. Moor and J. Burns. 1987. Soil hydrophobic effects on infiltration and catchment runoff. Hydrol. Process 3:211-222.

16. Chau, H. W., YK. Goh and V. Vujanovic. 2012. Wetting properties of fungi mycelium alter soil infiltration and soil water repellency in a $\gamma$ sterilized wettable and repellent soil. J. Fungal. Hydrol. 116: 1212-1218.

17. Dar, G. H. 1997. Impact of lead and sewage sludge on soil microbial biomass and carbon and nitrogen mineralization. Bulletin. Environ. Contamin. Tox. 58: 234-240.

18. DeBano, L. F. 1981. Water repellent soils: a state-of-the-art. 21 p. Gen. Technical Report PSW- 46. Berkeley, CA: U.S. Department of Agriculture, Forest Service, Pacific Southwest Forest and Range Experiment Station.

19. Dekker, L. W. and C. G. Ritsema. 1994. How water moves in a water repellent sandy soil. 1. Potential and actual water repellency. Water Resour. Res. 30: 2507-2517.

20. Epstein, E. 1975. Effect of sewage sludge on some soil physical properties. J. Environ. Qual. 4(1): 139-142.

21. Fernandes, S. A. P., W. Bettiol and C. C. Cerri. 2005. Effect of sewage sludge on microbial biomass, basal respiration, metabolic quotient and soil enzymatic activity. J. Appl. Soil. Ecol. 30: 65-77.

22. Gregorich, E.G., M. R. Carter., J. W. Doran, C. E. Dankhyrst and L. M. Dwyer. 1997. Biological attributes of soil quality. PP. 28: 81-104. In: E. G. Gregorich and M. R. Catrer (Ed.), Soil Quality for Crop Production and Ecosystem Health. Developments in Soil Science.

23. Imenson, A. C., J. M. Vertraten, E. J. Van Mullingen and J. Sevink. 1992. The effects of fire and water repellency on infiltration and runoff under Mediterranean type forests. Catena 19: 345-361.

24. Leoppert, R. H. and D. L. Sparks. 1996. Carbonate and gypsum. In: D. L. Sparks (Ed.), Methods of Soil Analysis. Part 3: chemical methods. SSSA Madison, WI.

25. McGhie, D. A. and A. M. Posner. 1981. The effect of plant top material on the water repellence of fired sands and water-repellent soils. Aust. J. Agri. Res. 32: 6090-620.

26. Nelson, D. W. and L. E. Summers. 1996. Total carbon organic carbon and organic matter. PP. 961-1010. In: D. L. Sparks (Ed.), Methods of Soil Analysis. Part 3, chemical methods. Soil Science Society of America, Madison, WI.

27. Ojeda, G. S., J. M. Mattana Alcaniz, G. Marando, M. Bonmati., S. K. Woche and J. Bachmam. 2010. Wetting Process and Soil Water retention of a minesoil amended with composted and thermally dried sludge. Geoderma156: 399-409.

28. Rilling, M. C. 2005. A connection between fungal hydrophobias and soil water repellency? Pedobiologia 49: $395-$ 399.

29. Rhoades, J. D. 1986. Soluble salts. PP. 167-179. In: Page AL, Miller R.H and Keeney D.R (Ed.), Methods of Soil Analysis. Part 2. Soil Sci. Soc. Am, Madison, WI.

30. Saadat, K., M. Barani Motlagh, E. Dordipour and A. Ghasemnezhad. 2012. Influence of sewage sludge on some soil properties, yield and concentration of lead and cadmium in roots and shoots of Maize. J. Soil. Manage. Sustain. 2: $27-48$.

31. Selivanovaskaya, Syu, V. Latypova, S. Kiyamova and F. Alimova. 2001. Use of microbial parameters to assess treatment methods of municipal sewage sludge applied to grey forest soils of Tatarstan. Agri., Ecosys. Environ. 86: 145-153.

32. Sharma, R. K., M. Arawal and F. M. Marshalla. 2006. Heavy metal contamination in vegetables grown in wastewater irrigated areas of Varanasi. India. Bulletion. Environ. contamin. Toxi. 77: 312-318.

33. Thomas, G. W. 1996. Soil pH and soil acidity. PP. 475-490. In: Method of Soil Analysis. Part3: chemical methods. Soil Science Society of America, Madison, WI.

34. Yaobing, S. M., L. Thampson and C. Shang. 1999. Fraction of phosphorus in a Mollisoil amended with biosolids J. Soil Sci. Soc. Am. 63: 1174-1180. 


\title{
The Effect of Urban Sewage Sludge on Chemical Properties, Soil Basal Respiration and Microbial Biomass Carbon in a Calcareous Silty Clay Loam Soil
}

\author{
N. Karimian-Shamsabadi, Sh. Ghorbani Dashtaki ${ }^{*}$ and F. Raiesi ${ }^{1}$
}

(Received: Feb. 15-2015 ; Accepted: Aug. 23-2016)

\begin{abstract}
The use of organic matter such as urban sewage sludge may help sustainable soil fertility via improving the physical, chemical and biological soil characteristics. The main purpose of this study was to determine the effect of urban sewage sludge on chemical properties, soil basal respiration and microbial biomass carbon in a calcareous soil with silty clay loam texture. Therefore, three levels of water repellency (zero, weak and strong) were artificially created in a silty clay loam soil by adding urban sewage sludge ( $\mathrm{S} 0=0: 100 ; \mathrm{S} 50=50: 50$ and $\mathrm{S} 80=80: 20$ sludge weight: soil ratio). Water repellency was determined by water drop penetration time (WDPT) method. Also some chemical properties such as soil acidity $(\mathrm{pH})$ and Electrical Conductivity (EC), Soil Organic Carbon (OC), soluble sodium $\left(\mathrm{Na}^{+}\right.$) and soluble potassium $\left(\mathrm{K}^{+}\right)$were measured. The samples were incubated at $23-25^{\circ} \mathrm{C}$ for 30 days and their moisture was maintained at $70-80 \%$ under field capacity and soil basal respiration and microbial biomass carbon of incubation period were evaluated. The results showed that the effect of urban sewage sludge on chemical properties was significant $(\mathrm{P} \leq 0.0001)$. The application of urban sewage sludge led to significant increase in basal respiration (16 and 27 times) and microbial biomass carbon (15.2 and 26.5 times) in the water repellency soils (S50 and S80) compared to control soil. The observed positive effect of sewage sludge might be due to a high content of organic carbon and nutrients in urban sewage sludge and decrease in the labile organic matter and nutrients during incubation period.
\end{abstract}

Keywords: Basal respiration, Microbial biomass carbon, Soil water repellency, urban sewage sludge

1. Dept. of Soil Sci., Faculty of Agric., Shahrekord Univ., Shahrekord, Iran.

*: Corresponding Author, Email:Shoja2002@yahoo.com 